он существовал на протяжении многих веков и выступал деструктивным фактором в установлении законности и достижении высокого уровня правовой культуры.

$$
* * *
$$

1. Венгеров А.Б. Теория государства и права: учебник для юридических вузов. - 3-е изд. - М.: Юриспруденция, 2000.

2. Гулина О.Р. Исторические корни и особенности правового нигилизма в современной России: дисс. ... канд. юрид. наук. - Уфа, 2002.

3. Общая теория государства и права: Академический курс: в 2т. / Под ред. М.Н. Марченко. - М., 1998. - T. 2.

4. Словарь иностранных слов. - М., 1983.

5. Туманов В.А. О правовом нигилизме / В.А. Туманов // Советское государство и право. - 1989. - № 10.

6. Теория государства и права. Курс лекций / Под ред. Н.И. Матузова и А.В. Малько. - М.: Юристъ, 2001

7. Теория государства и права / Отв. ред. В.М. Корельский, В.Д. Перевалов. - Екатеринбург, 1996.

8. Франк С.Л. Этика нигилизма // Вехи. - М., 1991.

9. Шепелев А.Н. Проблема изменения правового сознания в современном российском обществе / А.Н. Шепелев // Правовая политика и правовая жизнь. - 2003. - № 4.

\title{
Бялт В.С., Чимаров С.Ю. \\ Институт ограничений прав и свобод человека и гражданина в период действия военного положения
}

Санкт-Петербургский университет МВД России

(Россия, Санкт-Петербург)

doi: 10.18411/lj-08-2021-124

\section{Аннотация}

В статье авторы исследуют вопросы, связанные с возможностью правомерного ограничения прав и свобод человека и гражданина при введении на территории России военного положения. Анализируя действующие правовые нормы в указанной сфере, авторы, рассматривают возможные меры, ограничивающие права и свободы человека и гражданина, а также формулируют и обосновывают ряд выводов касательно исследуемой проблематики.

Ключевые слова: права, свободы, ограничение прав и свобод, правовой режим, военное положение.

\section{Abstract}

In the article, the authors investigate the issues related to the possibility of lawful restriction of human and civil rights and freedoms when martial law is imposed on the territory of Russia. Analyzing the current legal norms in this area, the authors consider possible measures that restrict the rights and freedoms of man and citizen, as well as formulate and justify a number of conclusions regarding the studied problem.

Keywords: rights, freedoms, restriction of rights and freedoms, legal regime, martial law.

Права и свободы человека и гражданина выступают основным элементом структуры правового статуса личности [9, с. 254]. Гарантированность соблюдения прав и свобод граждан является одним из признаков социального, правового государства $[11$, c. 5]. Президент России В. В. Путин подчеркивает, что необходимость соблюдения и защиты прав и свобод граждан является непосредственной обязанностью государства и напрямую связано с совершенствованием функционирования государственного механизма [7]. Сообразно с этим можно утверждать, что вопросы исследования 
реализации прав и свобод человека и гражданина, а также их соблюдение в условия чрезвычайной ситуации и военного времени являются весьма актуальными.

Основные права и свободы российских граждан закреплены в Конституции Российской Федерации. Все конституционные права и свободы можно подразделить на абсолютные, которые не подлежат ограничению, и относительные - права и свободы, которые могут быть ограничены в определенных случаях [8, с. 156]. Перечень абсолютных прав и свобод содержится в части 3 статьи 56 Конституции Российской Федерации.

В соответствии с Конституцией Российской Федерации «права и свободы человека и гражданина могут быть ограничены федеральным законом только в той мере, в какой это необходимо в целях защиты основ конституционного строя, нравственности, здоровья, прав и законных интересов других лиц, обеспечения обороны страны и безопасности государства» [1, ст. 55].

Одним из нормативных правовых актов, в соответствии с которым права и свободы российских граждан могут быть ограничены, является Федеральный Конституционный закон от 30 января 2002 года № 1-ФКЗ «О военном положении». Под военным положением понимается особый правовой режим, вводимый на территории Российской Федерации или в отдельных ее местностях в соответствии с Конституцией Российской Федерации Президентом Российской Федерации в случае агрессии против Российской Федерации или непосредственной угрозы агрессии [6, ст. 1]. Правовое положение граждан в период военного положения регламентируется статьей 18 указанного закона, согласно которой в период действия военного положения граждане пользуются всеми установленными правами и свободами, за исключением прав и свобод, ограничение которых установлено нормами федерального законодательства.

Ограничение прав и свобод в период военного времени обосновывается необходимостью выполнения установленных законодательством мер по организации производства продукции (выполнения работ, оказания услуг) для государственных нужд, обеспечения Вооруженных Сил Российской Федерации, других войск, воинских формирований и органов, специальных формирований, создаваемых на военное время и для нужд населения [10, с. 63]. [6, ст. 7]:

К числу мер, ограничивающих права и свободы граждан, относят следующее

- введение особого режима работы объектов, обеспечивающих функционирование транспорта, коммуникаций и связи, объектов энергетики, а также объектов, представляющих повышенную опасность для жизни и здоровья людей и для окружающей природной среды;

- эвакуация объектов хозяйственного, социального и культурного назначения, а также временное отселение жителей в безопасные районы с обязательным предоставлением таким жителям стационарных или временных жилых помещений;

— введение и обеспечение особого режима въезда на территорию, на которой введено военное положение, и выезда с нее, а также ограничение свободы передвижения по ней;

- приостановление деятельности политических партий, других общественных объединений, религиозных объединений, ведущих пропаганду и (или) агитацию, а равно иную деятельность, подрывающую в условиях военного положения оборону и безопасность Российской Федерации;

- привлечение граждан в порядке, установленном Правительством Российской Федерации, к выполнению работ для нужд обороны, 
ликвидации последствий применения противником оружия, восстановлению поврежденных (разрушенных) объектов экономики, систем жизнеобеспечения и военных объектов, а также к участию борьбе с пожарами, эпидемиями и эпизоотиями;

- изъятие в соответствии с федеральными законами необходимого для нужд обороны имущества у организаций и граждан с последующей выплатой государством стоимости изъятого имущества;

- запрещение или ограничение выбора места пребывания либо места жительства;

- запрещение или ограничение проведения собраний, митингов и демонстраций, шествий и пикетирования, а также иных массовых мероприятий;

- запрещение забастовок и иных способов приостановления или прекращения деятельности организаций;

- ограничение движения транспортных средств и осуществление их досмотра;

- запрещение нахождения граждан на улицах и в иных общественных местах в определенное время суток и предоставление федеральным органам исполнительной власти, органам исполнительной власти субъектов Российской Федерации и органам военного управления права при необходимости осуществлять проверку документов, удостоверяющих личность граждан, личный досмотр, досмотр их вещей, жилища и транспортных средств, а по основаниям, установленным федеральным законом, - задержание граждан и транспортных средств (при этом срок задержания граждан не может превышать 30 суток);

- введение военной цензуры за почтовыми отправлениями и сообщениями, передаваемыми с помощью телекоммуникационных систем, а также контроля за телефонными переговорами, создание органов цензуры, непосредственно занимающихся указанными вопросами;

- интернирование (изоляция) в соответствии с общепризнанными принципами и нормами международного права граждан иностранного государства, воюющего с Российской Федерацией и др.

Таким образом, можно констатировать, что нормы национального законодательства Российской Федерации охраняют и защищают права и свободы граждан, но вместе с тем и устанавливают возможность их ограничения в период действия военного положения.

Подводя итог вышеизложенному, можно сформулировать следующие выводы:

1) анализ института ограничений прав и свобод человека и гражданина в условиях военного положения, а в особенности его правомерности, занимает одно из ведущих мест в области осуществления теоретикоправовых изысканий;

2) ограничение прав и свобод граждан в период действия военного положения, несомненно, должно осуществляться в строгом соответствии с конституционными нормами и нормами федерального законодательства;

3) на наш взгляд, совершенствование нормативной правовой базы в сфере ограничения прав и свобод человека и гражданина в условиях военного времени, должно реализовываться в рамках конкретизации норм международного права $[2 ; 3 ; 4 ; 5]$, с учетом передового опыта правотворческой и правоприменительной деятельности в указанной 
сфере, а также с учетом анализа реализации национального законодательства в условиях военного времени и чрезвычайного положения;

4) с нашей точки зрения целесообразно рассмотреть вопрос о внесении в статью 22 Федерального конституционного закона «О военном положении» дополнения, касающегося установления конкретных сроков, в течении которых Президент Российской Федерации принимает меры по уведомлению Генерального секретаря Организации Объединенных Наций и информированию Генерального секретаря Совета Европы об отступлении Российской Федерации от своих обязательств по международным договорам, связанном с ограничением прав и свобод граждан; по нашему мнению данное дополнение будет полностью соответствовать пункту 3 статьи 4 Международного пакта о гражданских и политических правах.

$$
* * *
$$

1. Конституция Российской Федерации: Принята всенародным голосованием 12 декабря 1993 года // Российская газета, 1993, 25 декабря.

2. Конвенция об обращении с военнопленными (Женева, 12 августа 1949 года) // Международная защита прав и свобод человека. Сборник документов. - М.: Юрид. лит., 1990. С. 454512.

3. Конвенция о защите гражданского населения во время войны (Женева, 12 августа 1949 года) // Международная защита прав и свобод человека. Сборник документов. - М.: Юрид. лит., 1990. С. 512569.

4. Конвенция о защите культурных ценностей в случае вооруженного конфликта (Гаага, 14 мая 1954 года) // Ведомости Верховного Совета СССР. 1957. № 3, Ст. 54.

5. Международный пакт о гражданских и политических правах: принят 16 декабря 1966 года Резолюцией 2200 (XXI) на 1496-ом пленарном заседании Генеральной Ассамблеи ООН // // Ведомости Верховного Совета СССР. 1976. № 17, Ст. 291.

6. Федеральный конституционный закон от 30 января 2002 года № 1-ФКЗ «О военном положении» // С3 РФ. 2002. № 5. Ст. 375.

7. Послание Президента Российской Федерации Федеральному Собранию Российской Федерации от 15 января 2020 года // Российская газета, 2020, 16 января.

8. Агеева Ю.В. Конституционные права, свободы и обязанности человека и гражданина Российской Федерации // Международный журнал гуманитарных и естественных наук. 2020. № 62 (45). С. 156.

9. Бялт В.С. Теория государства и права в схемах: Учебное пособие. - М.: Издательство Юрайт, 2020. C. 254.

10. Войтов А.В. Военное положение как «элемент» государственности // Сборник научных работ серии «Право». 2020. № 2 (18). С. 63.

11. Малахов В.П. Социальное государство: эксперимент или закономерность развития // История государства и права. 2017. № 3. С. 5 .

\section{Бялт В.С., Чимаров С.Ю. \\ Юридическая техника: понятие и содержание}

Санкт-Петербургский университет МВД России (Россия, Санкт-Петербург)

doi: $10.18411 / \mathrm{j}-08-2021-125$

\section{Аннотация}

Статья посвящена исследованию юридической техники с позиции анализа ее содержания. Авторы, рассматривая различные подходы к пониманию юридической техники, формулируют понятие «юридическая техника» через раскрытие ее содержания.

Ключевые слова: юридическая техника, юридическая деятельность, юридические документы, средства, правила и приемы юридической техники. 